\title{
High-frequency monitoring of water fluxes and nutrient loads to assess the effects of controlled drainage on water storage and nutrient transport
}

\author{
J. C. Rozemeijer ${ }^{1}$, A. Visser ${ }^{2}$, W. Borren ${ }^{1}$, M. Winegram ${ }^{3}$, Y. van der Velde ${ }^{4}$, J. Klein ${ }^{1}$, and H. P. Broers ${ }^{5}$ \\ ${ }^{1}$ Deltares, P.O. Box 85467, 3508 AL Utrecht, the Netherlands \\ ${ }^{2}$ Lawrence Livermore National Lab, P.O. Box 808, Livermore, CA 94551-0808, USA \\ ${ }^{3}$ Allseas Engineering, Poortweg 12, 2612 PA Delft, the Netherlands \\ ${ }^{4}$ Department of Earth Sciences, VU University Amsterdam, Boelelaan 1085, $1081 \mathrm{HV}$ Amsterdam, the Netherlands \\ ${ }^{5}$ TNO Geological Survey of the Netherlands, P.O. Box 80015, 3508 TA Utrecht, the Netherlands
}

Correspondence to: (joachim.rozemeijer@deltares.nl)

Received: 1 May 2015 - Published in Hydrol. Earth Syst. Sci. Discuss.: 30 June 2015

Revised: 29 October 2015 - Accepted: 14 December 2015 - Published: 19 January 2016

\begin{abstract}
High nitrogen (N) and phosphorus (P) fluxes from upstream agriculture threaten aquatic ecosystems in surface waters and estuaries, especially in areas characterized by high agricultural $\mathrm{N}$ and $\mathrm{P}$ inputs and densely drained catchments like the Netherlands. Controlled drainage has been recognized as an effective option to optimize soil moisture conditions for agriculture and to reduce unnecessary losses of fresh water and nutrients. This is achieved by introducing control structures with adjustable overflow levels into subsurface tube drain systems. A small-scale (1 ha) field experiment was designed to investigate the hydrological and chemical changes after introducing controlled drainage. Precipitation rates and the response of water tables and drain fluxes were measured in the periods before the introduction of controlled drainage (2007-2008) and after (20092011). For the $\mathrm{N}$ and $\mathrm{P}$ concentration measurements, autoanalyzers for continuous records were combined with passive samplers for time-averaged concentrations at individual drain outlets. The experimental setup enabled the quantification of changes in the water and solute balance after introducing controlled drainage. The results showed that introducing controlled drainage reduced the drain discharge and increased the groundwater storage in the field. To achieve this, the overflow levels have to be elevated in early spring, before the drain discharge stops due to dryer conditions and falling groundwater levels. The groundwater storage in the field would have been larger if the water levels in the adja-
\end{abstract}

cent ditch were controlled as well by an adjustable weir. The $\mathrm{N}$ concentrations and loads increased, which was largely related to elevated concentrations in one of the three monitored tube drains. The $\mathrm{P}$ loads via the tube drains reduced due to the reduction in discharge after introducing controlled drainage. However, this may be counteracted by the higher groundwater levels and the larger contribution of $\mathrm{N}$ - and P-rich shallow groundwater and overland flow to the surface water.

\section{Introduction}

High nitrogen $(\mathrm{N})$ and phosphorus $(\mathrm{P})$ fluxes from agricultural areas threaten aquatic ecosystems in downstream surface waters, estuaries, and coastal zones around the world (e.g., Foley et al., 2005; Howarth, 2008). The effects of eutrophication, such as loss of biodiversity and toxic algal blooms threaten the industrial, recreational, and ecological functions of water resources (e.g., Makarewic et al., 2007; Weijters et al., 2009; Díaz and Rosenberg, 2011). The adverse effects of high nutrient inputs are most prominent in stagnant water bodies, with long residence times and low vertical and horizontal mixing, such as shallow lakes, bays and harbors. Current hotspots are the Gulf of Mexico, Chesapeake Bay, the Great Lakes in North America, and the Baltic Sea and the North Sea in Europe. In addition, eutrophicationrelated problems arise in developing areas such as China, 
Southeast Asia, and South America (Seitzinger et al., 2010). Global changes, such as population growth and climate change, further increase the pressures on water resources and their vulnerability for eutrophication (e.g., Statham, 2012; Seitzinger et al., 2010).

Controlled drainage has been recognized as an effective option to optimize soil moisture conditions for agriculture and to reduce unnecessary losses of fresh water and nutrients. The strategy of controlled drainage is to stop draining as long as agricultural productivity is not threatened by wet conditions. This is achieved by control structures with adjustable overflow levels in subsurface tube drain systems. Several pilot studies (e.g., Evans et al., 1995; Wesström and Messing, 2007; Jaynes, 2012, Helmers et al., 2012) reported significant reductions in discharge of water via tube drains $(-16$ up to $-89 \%$ ). Although the nitrogen concentrations in the drain effluent did not change in most cases, the reduced water discharge also reduced the nitrogen export via tube drains $(-18$ up to $-82 \%)$.

None of the reported studies quantified the changes of nutrient export via other flow routes, such as shallow groundwater flow and overland flow. Therefore, the fate of the reduced water and nutrient exports often remains unknown (Woli et al., 2011). Ideally, the conserved water and nutrients enhance crop production. However, the reported effects of controlled drainage on crop production vary between no significant change up to an increase of $19 \%$ at individual fields (Wesström and Messing, 2007; Ghane et al., 2012). Considering the limited increase in water and nutrient uptake by crops, the possibility comes up that water and nutrients are still exported towards the surface water via enhanced overland or shallow groundwater flow.

This study aimed to quantify the effects of controlled drainage on water and nutrient exports from an agricultural field to the surface-water system. A small-scale (1 ha) field experiment was designed to investigate the changes in flow route contributions towards surface water after introducing controlled drainage. Precipitation rates and the response of water tables and drain fluxes were measured in the period before the introduction of controlled drainage (2007-2008) and after (2009-2011). For the N and P concentration measurements, auto-analyzers for continuous records were combined with passive samplers for time-averaged concentrations at individual drain outlets. This setup enabled us to quantify the changes in the field water and solute balance after introducing controlled drainage.

\section{Methods}

\subsection{Study area}

The experimental setup was installed in the Hupsel catchment $\left(6.64 \mathrm{~km}^{2}\right)$ in the eastern part of the Netherlands (Fig. 1; 52 $04^{\prime} 01.5^{\prime \prime} \mathrm{N}, 6^{\circ} 39^{\prime} 29.0^{\prime \prime} \mathrm{E}$ ). The surface elevations

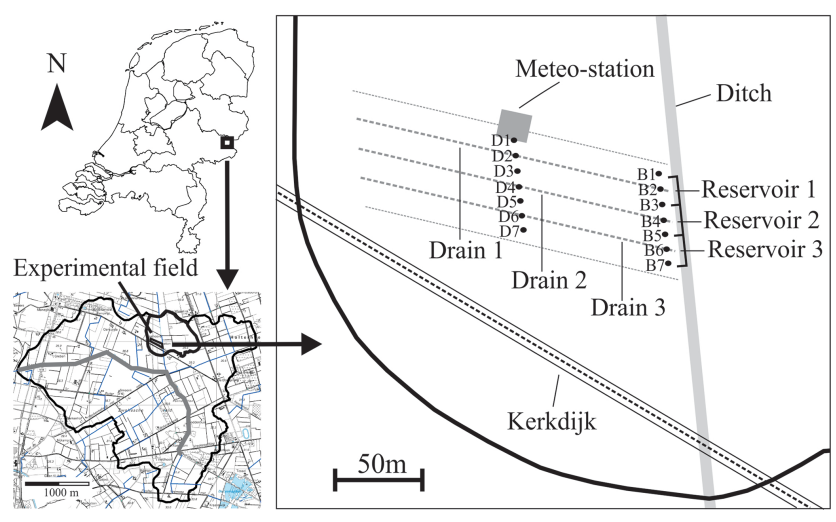

Figure 1. Location of the Hupsel catchment and the experimental field. The field sketch shows the three measured tube drains, the location of the in-stream reservoirs, and the locations of the continuous groundwater level recording in transects at $5 \mathrm{~m}$ from the ditch (B1-B7) and at $80 \mathrm{~m}$ from the ditch (D1-D7).

in the catchment range from 22 to $36 \mathrm{~m}$ above sea level (a.s.1.) and the land use is predominantly agricultural with maize and grassland. At depths ranging from 0.5 to $20 \mathrm{~m}$ a $20-30 \mathrm{~m}$ thick impermeable marine clay layer of Miocene age is found of which the top is carved by glacial erosion. This clay layer forms a natural lower boundary for the unconfined groundwater flow (Van Ommen et al., 1989; Van der Velde et al., 2010, 2011). The unconfined aquifer consists of Pleistocene eolian sands with occasional layers of clay, peat, and gravel. Wösten et al. (1985) classified the main soil type of the catchment as sandy, siliceous, mesic Typic Haplaquads. The catchment is drained by a dense network of artificial ditches and subsurface tube drains. The spacing between the ditches averages $300 \mathrm{~m}$ and tube drainage is installed in more than $50 \%$ of the area; see Van der Velde et al. (2010) for a more detailed description of the Hupsel catchment.

For the field-scale evaluation of controlled drainage, a 0.9 ha grass field in the northern part of the catchment was selected. Within this field, surface elevations range between 27.5 and $28.5 \mathrm{~m}$ a.s.l. The subsurface consists of a $3-4 \mathrm{~m}$ thick unconfined sandy aquifer of Pleistocene aeolian sands. Below this, a $20-30 \mathrm{~m}$ thick impermeable marine clay layer of Miocene age forms the natural lower boundary for the unconfined groundwater flow (Van Ommen et al., 1989). Subsurface drain tubes of $5 \mathrm{~cm}$ in diameter are present with spaces of $14.5 \mathrm{~m}$ between individual drains. The drains discharge into the ditch at $90 \mathrm{~cm}$ below the field surface level. Over their $200 \mathrm{~m}$ length the tubes slope upward by $20-60 \mathrm{~cm}$ away from the ditch, depending on the local topography (Rozemeijer et al., 2010b). Rozemeijer et al. (2010a) quantified that the tube drains contributed $80 \%$ of the total yearly water discharge to the surface water and $90 \%$ of the total yearly $\mathrm{NO}_{3}-\mathrm{N}$ and $\mathrm{P}$ export. 


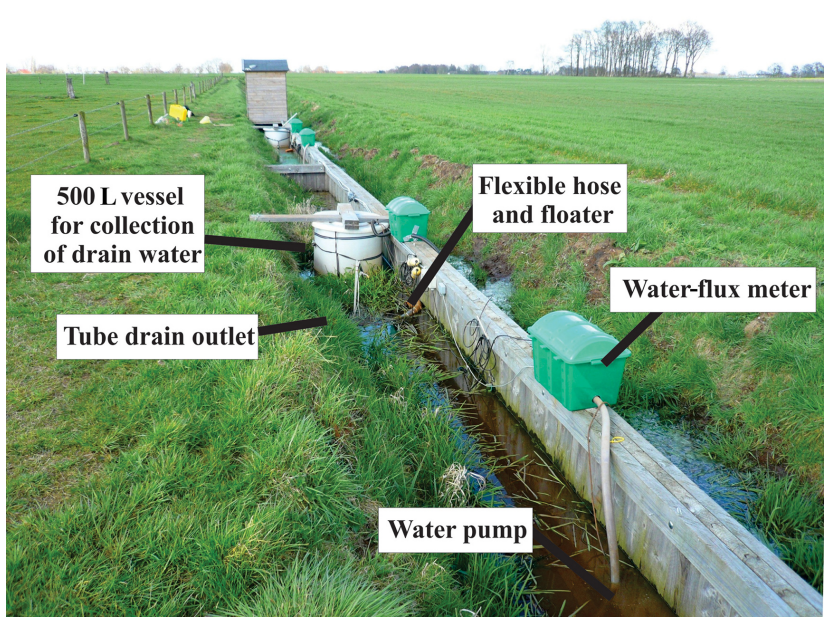

Figure 2. Picture of the complete setup with collector vessels for drain discharge, pumps, and water-flux meters. The shed in the back houses the data acquisition and control equipment.

\subsection{Experimental setup reference period}

The water and nutrient fluxes at the experimental field were monitored for the reference situation with conventional drainage from May 2007 to December 2008. During the summer of 2009, the setup was extended and controlled drainage was introduced. This approach enabled us to study the hydrological and chemical changes after introducing controlled drainage. A reference field without controlled drainage was not included in the experimental setup. The large spatial variability in hydrology and nutrient concentrations (see also Rozemeijer et al., 2010c) would not allow for an appropriate comparison between a pilot and a reference field. This was also concluded by Heinen et al. (2012), who studied the field-scale effects of buffer strips at a nearby experimental field.

The monitoring for the controlled drainage period was from November 2009 to September 2011. The farmer's land management did not change during this period. During both periods, the field was used for grass harvesting and cattle grazing. Manure was applied at the experimental field up to the maximum allowed $170 \mathrm{~kg} \mathrm{~N} \mathrm{ha}^{-1} \mathrm{yr}^{-1}$ during both the reference and the controlled drainage period.

The experimental setup for the reference period is described in detail by Van der Velde et al. (2010). The tube drain effluent was physically separated from the groundwater and overland flow routes towards a $43.5 \mathrm{~m}$ long section of the ditch (Fig. 1). To separate the fluxes toward the ditch via different routes, three adjacent sheet pile reservoirs were built (Fig. 2). These in-stream reservoirs were constructed around the outlets of drains 1,2, and 3 and captured overland flow, interflow, direct precipitation, and groundwater inflow from the thin aquifer above the Miocene clay. Excess water was pumped from the in-stream reservoirs into the ditch and the pumped volumes were recorded with digital flux meters with an accuracy of $2 \%$.

The effluent from the tube drains was separated from the other flow routes by connecting each drain outlet to a $500 \mathrm{~L}$ vessel using a flexible tube (Fig. 2). In an undisturbed situation, the surface-water pressure would affect the tube drain flow rates when the drain outlets are submerged. To imitate this effect, floaters were attached to the flexible tubes that connected the drains to the collection vessels. Thus, water leaving the drain had to flow up to the ditch water level before being discharged into the vessel (Van der Velde et al., 2010). After reaching a maximum water level in the vessel, the water was pumped into the ditch and the flux was measured with digital water-flux meters. On an average day during the drainage season, the vessels filled and emptied every $2 \mathrm{~h}$.

In addition to the discharge measurements, phreatic groundwater levels were measured weekly on 14 locations in transects at $5 \mathrm{~m}$ from the ditch and at $80 \mathrm{~m}$ from the ditch (Fig. 1). The meteorological data were derived from the Royal Dutch Meteorological Institute (KNMI) weather station adjacent to the experimental field (Fig. 1).

During the reference period, water quality samples were taken weekly from the three in-stream reservoirs and from the three drain effluent vessels. The samples were taken using a peristaltic pump and filtered in situ $(0.45 \mu \mathrm{m})$. Electrical conductivity and the $\mathrm{pH}$ of the samples were measured directly in the field. Sub-samples for ICP (inductively coupled plasma) analysis were directly acidified with $\mathrm{HNO}_{3}$. All samples were transported and stored at $4{ }^{\circ} \mathrm{C}$. The samples were analyzed within $48 \mathrm{~h}$ using IC $\left(\mathrm{NO}_{3}-\mathrm{N}, \mathrm{SO}_{4}, \mathrm{Cl}\right)$, ICPAES (inductively coupled plasma atomic emission spectrometry) ( $\mathrm{Na}, \mathrm{K}, \mathrm{Ca}, \mathrm{Fe}, \mathrm{Mg}, \mathrm{Si}$ ), ICP-MS (inductively coupled plasma mass spectrometry) (P, $\mathrm{Al}, \mathrm{Ni}, \mathrm{Cu}, \mathrm{Zn}, \mathrm{Cd}, \mathrm{Pb}$ ), AA $\left(\mathrm{NH}_{4}\right) . \mathrm{HCO}_{3}$ was measured by titration. Samples with deviating results for ions measured by more than one analytical method as well as samples with an ionic unbalance larger than $10 \%$ were reanalyzed.

In addition to the grab sampling, SorbiCell samplers (De Jonge and Rothenberg, 2005) were used for monthly timeaveraged $\mathrm{NO}_{3}-\mathrm{N}$ concentration measurements of tube drain effluent. The SorbiCell samplers were applied to measure average $\mathrm{NO}_{3}-\mathrm{N}$ concentrations for individual drains. An evaluation of SorbiCells based on duplicate analyses and comparison to conventional grab sampling and continuous measurements was published by Rozemeijer et al. (2010c). The SorbiCells proved to be capable of reproducing the $\mathrm{NO}_{3}$ concentration levels and the seasonal patterns that were observed with weekly conventional grab sampling and continuous water quality measurements.

\subsection{Experimental setup controlled drainage period}

For studying the effects of controlled drainage, the monitoring setup for the second period (2009-2011) was changed to 

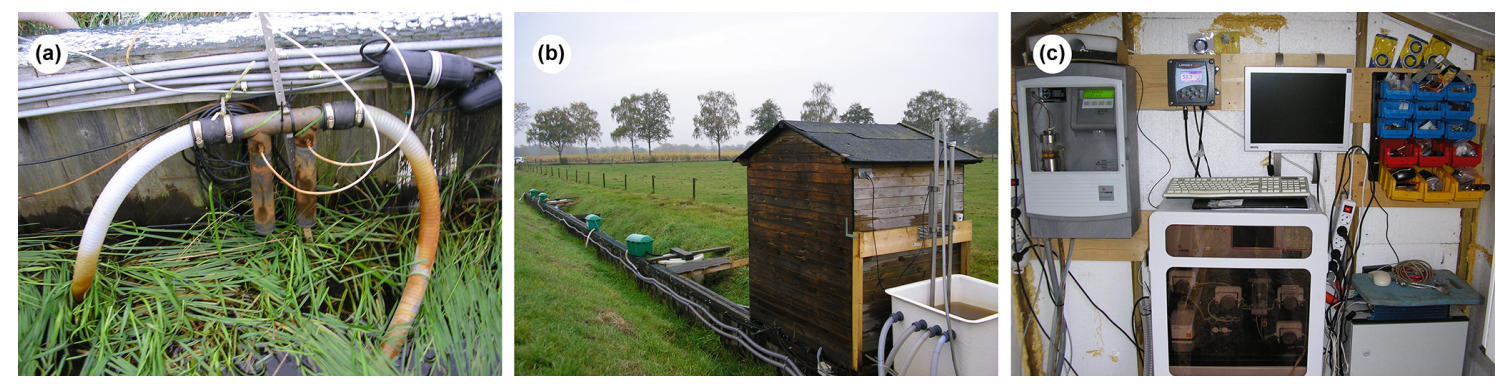

Figure 3. Pictures of the controlled drainage period setup: (a) the drainage overflow levels were adjusted by attaching the flexible connection tube (with a SorbiCell socket between the black fasteners) at the desired level; (b) the tube drain effluent was pumped to a collection vessel to enable continuous monitoring of $\mathrm{NO}_{3}-\mathrm{N}$ and total-P concentrations using a Nitratax-UV sensor and a Phosphax auto-analyzer (c).

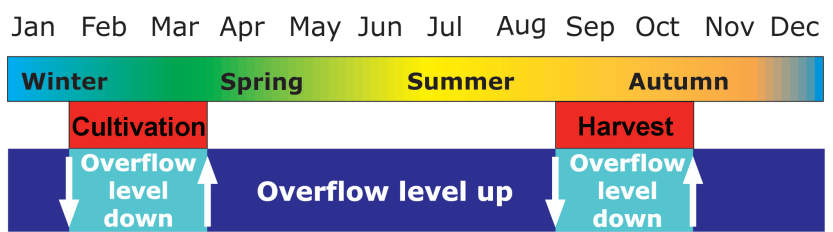

Figure 4. Drainage overflow level management schedule. The overflow levels were elevated most of the time, but were lowered in early spring and, if needed, in autumn to accommodate manure application and harvest.

focus more on the tube drains. The monitoring of the groundwater and overland flow contributions towards the in-stream reservoirs was stopped. The overflow levels of the drains were controlled by attaching the flexible connection tubes between the drain outlets and the collection vessels at the desired level (Fig. 3a). In the reference setup, the connection tubes were kept just below the water table in the reservoir using floaters. The excess water from the three drainage effluent vessels was collected in a combined reservoir (Fig. 3b). This enabled continuous registration of $\mathrm{NO}_{3}-\mathrm{N}$ and total-P concentrations of the combined drain effluent, for which a Nitratax-UV sensor and a Phosphax auto-analyzer were used (both Hach, Germany; Fig. 3c). More details on these technologies are provided by Van der Grift et al. (2015). Phreatic groundwater levels were monitored continuously using pressure sensors in all 14 piezometers in transects B and D. The high-resolution measurements enabled us to measure the direct responses of groundwater levels, drain discharges, and drain effluent nutrient concentrations after changing the overflow levels of the drains.

The overflow levels of the drains were adjusted following the scheme in Fig. 4. The exact adjustment moments are shown in the results section. To conserve as much water as possible, the overflow levels were elevated during most of the year. However, the field had to be dry enough for manure spreading after the end of the winter ban on manure spreading on 15 February. Like many farmers, the land owner has a limited storage capacity for manure, which forces him to apply manure as early as possible after 15 February. To enable manure spreading, the overflow levels were lowered to the original drain outlet levels during February and March. In the case of wet conditions at the end of the summer (grass harvest, manure spreading), the overflow levels were also lowered in consultation with the land owner.

\section{Results}

\subsection{Water levels, flows, and water balances}

The most important quantitative hydrological monitoring results are summarized in Fig. 5. The overflow levels of the drain outlets were elevated for the first time in November 2009. Initially, the overflow level was raised up to $20 \mathrm{~cm}$ above the drain outlet levels. Starting in mid-December 2009, the overflow levels were raised up to $+50 \mathrm{~cm}$. In early spring 2010 , the overflow levels were lowered to $+35 \mathrm{~cm}$ to enable the first manure application. In the wet autumn 2010 period, and in early spring 2011, the overflow levels were lowered down to the original drain outlet level. During the second drainage season with controlled drainage (2010-2011) we elevated and lowered the overflow levels with $50 \mathrm{~cm}$ on each occasion in order to bring about more distinct changes in groundwater levels, drain discharges, and nutrient losses compared to the first season (2009-2010).

The groundwater levels were above the tube drain level during the winter drainage period (Fig. 5). The differences between the individual piezometers in each transect were low, which indicates a minor groundwater level curvature between the drains. The winter groundwater levels were higher during the controlled drainage period compared to the reference period, especially in piezometers of transect D at $80 \mathrm{~m}$ from the ditch. The total amount of precipitation was higher in the reference drainage season compared to the controlled drainage period (see also Table 1). This indicates that the higher groundwater levels during the controlled drainage period could not have been caused by weather conditions, but rather by the elevated overflow level of the drains.

During the controlled drainage period, the groundwater levels were above the land surface more frequently and for 


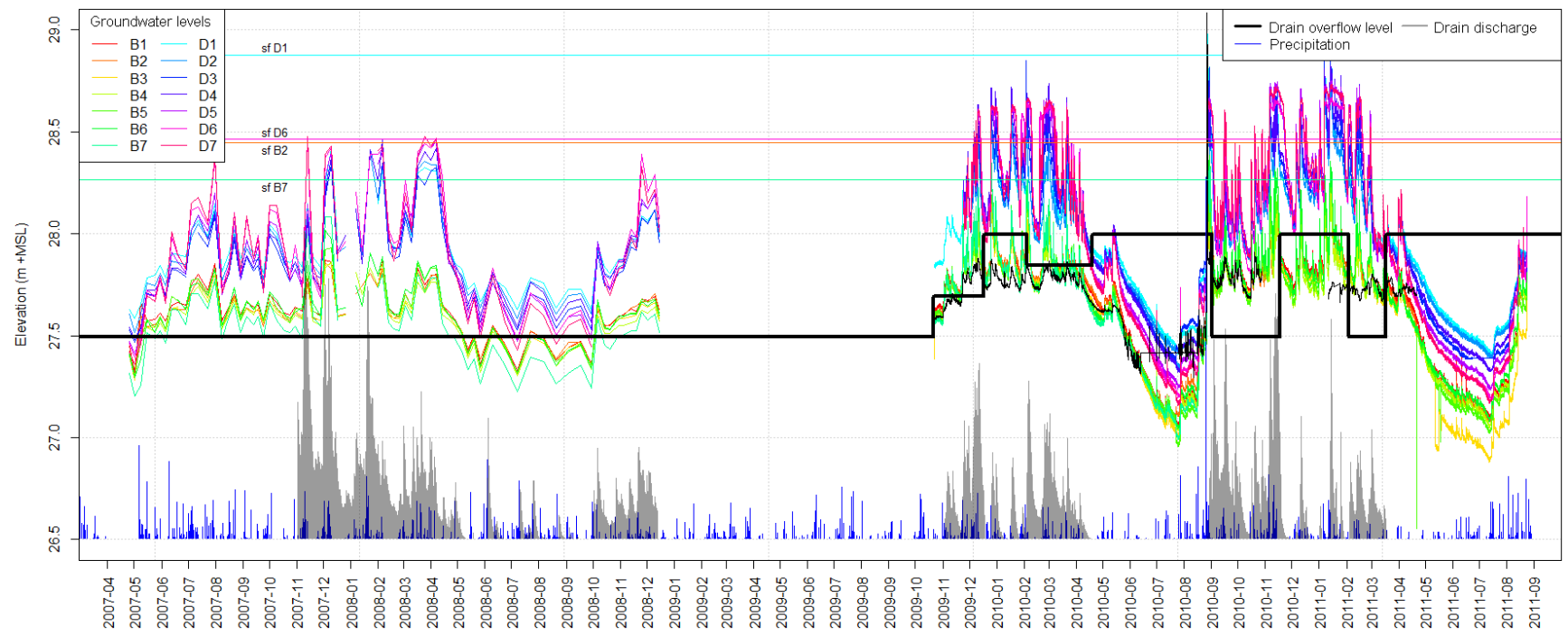

Figure 5. Combined results of hydrological measurements. The time series shown are (1) the overflow level of the drains (fixed at 27.5 in reference period, variable in controlled drainage period) in black, (2) the groundwater levels of the two transects B and D, and (3) in the lower part the drainage flux (grey) and precipitation (blue). The surface elevations at the lowest and highest groundwater monitoring locations of transects B and D are shown in colored horizontal lines.

Table 1. Water balances for a reference drainage season (2007-2008) and two controlled drainage seasons (2009-2010 and 2010-2011).

\begin{tabular}{lr|rr}
\hline & Reference & \multicolumn{2}{|c}{ Controlled drainage } \\
\cline { 2 - 4 } Water balance period & 2 Nov 2007- & 2 Nov 2009- & 2 Nov 2010- \\
& 2 Apr 2008 & 2 Apr 2010 & 2 Apr 2011 \\
\hline Precipitation (mm) & +387 & +331 & +300 \\
Evapotranspiration $(\mathrm{mm})$ & -51 & -47 & -50 \\
Discharge via drains (mm) & -303 & -163 & -127 \\
Discharge via groundwater (mm) & -51 & -63 & -68 \\
Discharge via overland and biopore flow (mm) & -28 & -20 & -34 \\
Compensation groundwater storage change (mm) & -108 & -46 & +26 \\
Net inflow from surroundings (mm) & +154 & +8 & -47 \\
\hline
\end{tabular}

longer periods, which indicates that ponding and overland flow became more important. Ponding and overland flow at the experimental field, as well as its relation with the groundwater levels, have been observed and reported by Van der Velde et al. (2010).

The groundwater levels at $5 \mathrm{~m}$ from the ditch in transect B were less affected by controlled drainage than the groundwater levels at $80 \mathrm{~m}$ from the ditch in transect D. The most evident difference between the responses of transects B and D was in November 2010, when the overflow levels were raised to $+50 \mathrm{~cm}$. Before this, the groundwater level difference between transects B and D averaged $15 \mathrm{~cm}$. After elevating the overflow levels, the difference increased up to ca. $50 \mathrm{~cm}$.

The tube drain fluxes were clearly affected by the changes in overflow levels during the controlled drainage period. During the reference period, the drains were active for several periods during the summer period of 2009. In the controlled drainage period, the tube drainage flow stopped after raising the overflow levels in spring 2010 and 2011. No drainage flow was registered during the subsequent summer periods. However, the drainage flow was immediately re-activated after lowering the overflow levels. This effect was most prominent in the 2010-2011 drainage period, when the overflow levels were lowered by $50 \mathrm{~cm}$ on two occasions, resulting in an immediate re-activation of the tube drain discharge.

Table 1 shows the comparison of the field water balances of the drainage seasons during the reference and the controlled drainage periods. The water balances of Table 1 focus on the winter drainage periods when the differences between conventional and controlled drainage were most pronounced. The precipitation and evapotranspiration data in the water balances were derived from the weather station next to the field. The drain discharge was directly measured during the reference and controlled drainage period. The groundwater and overland/biopore discharge towards the $45 \mathrm{~m}$ ditch transect were directly measured during the reference period (Van 

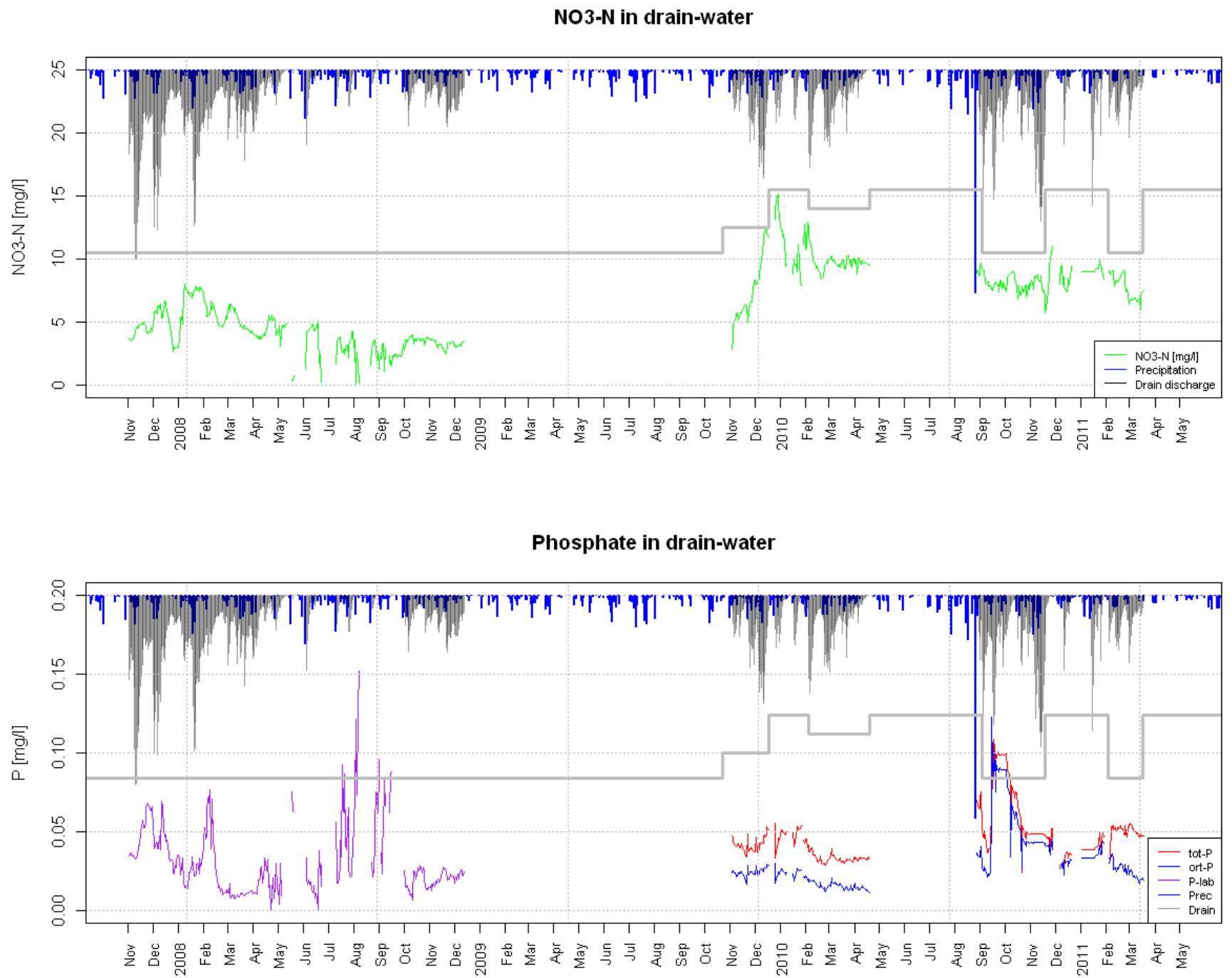

Figure 6. Measured nutrient concentrations in drain effluent. Precipitation (blue), drain discharge (grey), and the overflow levels are also plotted.

der Velde et al., 2010). Winegram (2012) used the measured groundwater discharges and groundwater level gradients to estimate the average saturated conductivity $(k)$. This conductivity, together with the groundwater level gradients measured during the reference period, was used to estimate the groundwater discharge during the controlled drainage period. A similar approach was used to estimate the overland and biopore flow volumes during the controlled drainage period. In this case, Winegram (2012) related the measured overland and biopore flow during the reference period to the amount of precipitation that fell on ponded parts of the field. The storage change in the water balance was derived from the difference in groundwater levels between the start and the end of the water balance periods. The net influx (or outflux) from the surrounding fields via regional groundwater flow cannot be measured, but was likely to occur and was needed to close the water balance for which the other fluxes were accurately measured (Van der Velde et al., 2010). More details on the water balance for the reference period were reported in Van der Velde et al. (2010) and for the controlled drainage period in Winegram (2012) and Rozemeijer et al. (2012).

When comparing the water balances for the reference period with the controlled drainage period, the differences in precipitation input and the groundwater storage change should be considered. The reference period was wetter than both controlled drainage periods, which may explain part of the differences in the discharges via groundwater, tube drains, and overland flow in the water balances. In addition, the groundwater levels rose during the reference water balance period. This change in groundwater storage during the reference period is compensated with a negative water volume $(-108 \mathrm{~mm})$, indicated as "compensation groundwater storage change" in the water balances in Table 1. During the first controlled drainage period, a smaller rise in groundwater 


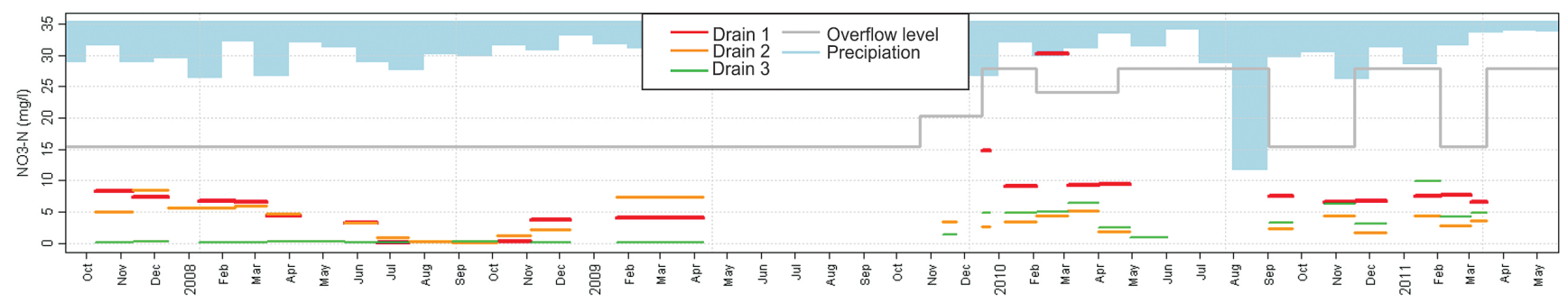

Figure 7. Results of the SorbiCell average $\mathrm{NO}_{3}-\mathrm{N}$ concentration measurements for the individual drains.

levels was measured. During the second controlled drainage period the groundwater levels dropped slightly, which is compensated for in the water balance with a positive volume $(+26 \mathrm{~mm})$.

The discharge via the tube drains was significantly lower in the controlled drainage periods compared to the reference period: $-46 \%$ in $2009-2010$ and $-58 \%$ in $2010-2011$. The discharge via groundwater increased slightly. Overland flow was slightly less in 2009-2010 and more in 2010-2011. However, these small changes in groundwater discharge and overland flow cannot compensate for the large reduction in discharge via drains. This compensation mainly comes from the net inflow of water from the surrounding fields. During the reference period, the field received a substantial influx of water from the surroundings $(+154 \mathrm{~mm})$. This influx was almost absent $(+8 \mathrm{~mm})$ during the first controlled drainage period. During the second controlled drainage period, a net outflux $(-47 \mathrm{~mm})$ from the field towards the surroundings was found. The change from a net influx to a net outflux is related to the elevated groundwater levels at the experimental field in the controlled drainage period.

\subsection{Nutrient concentrations and loads}

The measured nutrient concentrations $\left(\mathrm{NO}_{3}-\mathrm{N}, \mathrm{P}_{\text {tot }}, \mathrm{PO}_{4}\right)$ in tube drain effluent for the reference period and the controlled drainage period are shown in Fig. 6. During the reference period, the $\mathrm{NO}_{3}-\mathrm{N}$ concentrations varied between ca. $6 \mathrm{mg} \mathrm{NL}^{-1}$ in winter and $3 \mathrm{mg} \mathrm{N} \mathrm{L}^{-1}$ in summer. During the controlled drainage period, higher $\mathrm{NO}_{3}-\mathrm{N}$ concentrations of $8-10 \mathrm{mg} \mathrm{N} \mathrm{L}^{-1}$ were recorded. The concentrations were well above the surface-water quality standard of $2.3 \mathrm{mg} \mathrm{NL}^{-1}$ (Van der Molen et al., 2012). The $\mathrm{NO}_{3}-\mathrm{N}$ concentrations did not directly respond to changes in the overflow levels of the drains. However, the $\mathrm{NO}_{3}-\mathrm{N}$ concentrations increased upon the rewetting of the field and the increase of groundwater levels during November and December 2008. Although this increase in groundwater levels and $\mathrm{NO}_{3}-\mathrm{N}$ concentrations is a common seasonal pattern, elevating the overflow levels of the tube drains further increased both the groundwater levels and $\mathrm{NO}_{3}-\mathrm{N}$ concentrations. The increase of $\mathrm{NO}_{3}-\mathrm{N}$ concentrations is related to the activation of near-surface $\mathrm{NO}_{3}-\mathrm{N}$ rich groundwater flow routes towards the tube drains. The described autumn rewetting pattern is less clear in 2010, when a large precipitation event in August caused an immediate rewetting of the field and activation of $\mathrm{NO}_{3}$-rich tube drainage.

For $\mathrm{P}$, low concentrations were measured, both before and after the introduction of controlled drainage. Unlike $\mathrm{NO}_{3}-\mathrm{N}$, the $\mathrm{P}$ concentrations did not increase during rewetting in autumn. The low $\mathrm{P}_{\text {tot }}$ concentrations are related to the $\mathrm{P}$ immobilization in the tube drains due to adsorption to iron oxides (Van der Grift et al., 2014). During the 2010-2011 drainage season, the $\mathrm{P}_{\text {tot }}$ concentrations did increase after lowering the overflow levels with $50 \mathrm{~cm}$ and thereby increasing the drain effluent flow velocities. This caused uptake and transport of the $\mathrm{P}$-rich iron oxides and higher $\mathrm{P}$ concentrations in the tube drain effluent.

The results of the SorbiCell average concentration measurements for the individual drains are shown in Fig. 7. The data show that the largest increase in $\mathrm{NO}_{3}-\mathrm{N}$ concentrations occurred in drain 3. During the reference period, the effluent from this drain showed $\mathrm{NO}_{3}-\mathrm{N}$ concentrations close to zero. In the controlled drainage period, however, the $\mathrm{NO}_{3}-\mathrm{N}$ concentrations were between the concentrations measured in drain 1 and 2.

Cumulative plots of the nutrient loads from the three drains are shown in Fig. 8, together with the cumulative precipitation and drain discharge. The $\mathrm{NO}_{3}-\mathrm{N}$ and $\mathrm{P}$ loads for distinct periods are given in Table 2. The first three periods in Table 2 give the loads for periods of a total year. Comparing both controlled drainage years (periods 2 and 3 ) with the reference (period 1) shows that the $\mathrm{P}$ loads were reduced after introducing controlled drainage. The P-load/precipitation ratios were also lower for the controlled drainage periods 2 and 3 than for the reference period. For $\mathrm{NO}_{3}-\mathrm{N}$; however, the yearly $\mathrm{NO}_{3}-\mathrm{N}$ loads were higher in the controlled drainage periods. This is related to the higher $\mathrm{NO}_{3}-\mathrm{N}$ concentrations in drain effluent after the introduction of controlled drainage, especially in period 2.

The impact of adjusting the overflow levels on nutrient loads is most clear in the 2010-2011 drainage period, when large adjustments of the overflow levels were made. Elevating the overflow levels reduced the drainage flux and loads, as indicated by the leveling of the cumulative graphs in Fig. 8 and by the lower loads and load/precipitation ratios during 

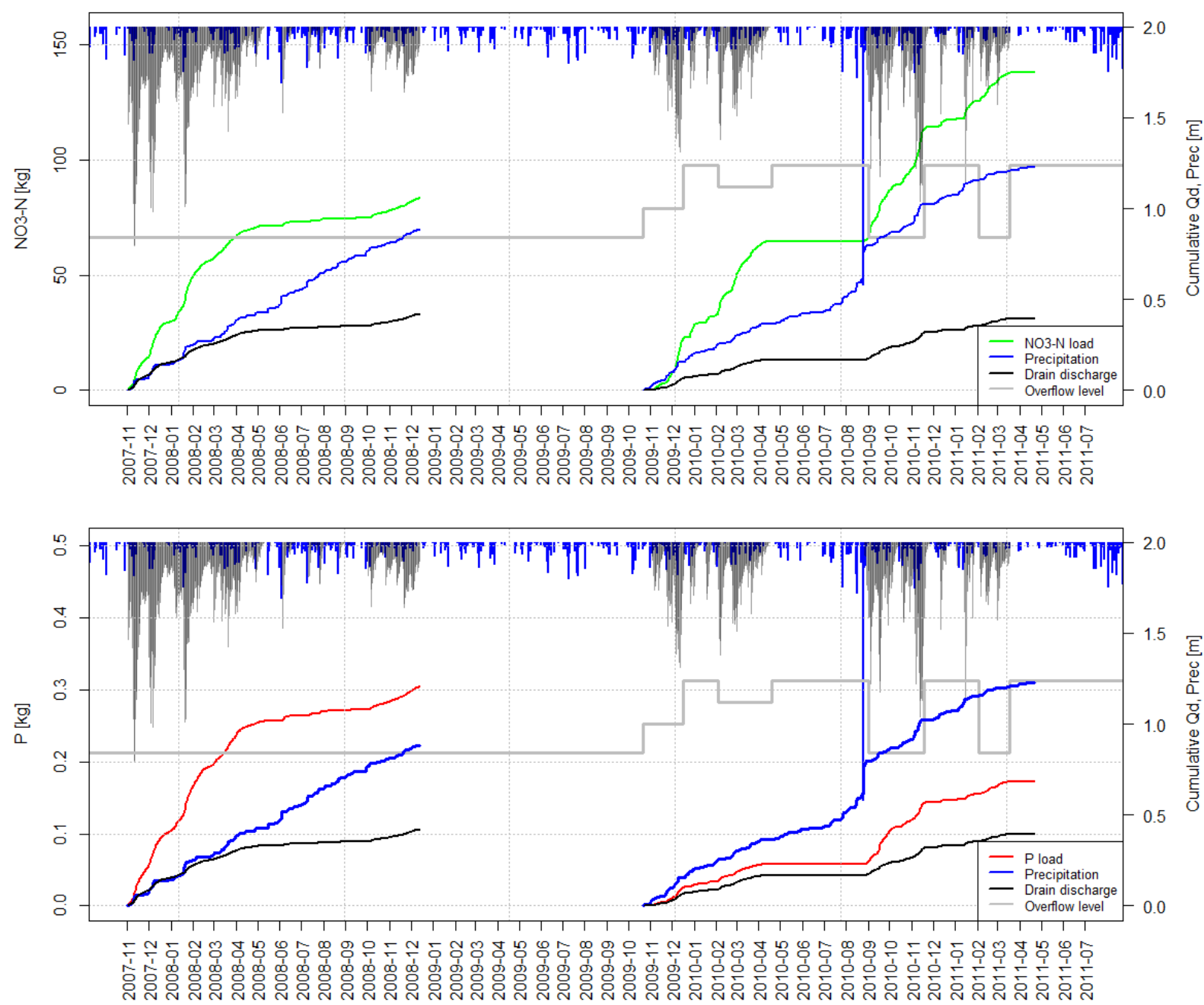

Figure 8. Cumulative precipitation, drain discharge, and drain $\mathrm{NO}_{3}-\mathrm{N}$ and $\mathrm{P}_{\text {tot }}$ loads.

Table 2. Comparison of $\mathrm{NO}_{3}-\mathrm{N}$ and $\mathrm{P}$ loads in the combined discharge of three drains between distinct periods. Precipitation and the ratios between loads and precipitation are also shown. The first three periods cover total years; the others compare shorter periods within the drainage season.

\begin{tabular}{llllrrrrr}
\hline Period & Drainage level & Start & End & $\begin{array}{r}\text { Precipitation } \\
(\mathrm{mm})\end{array}$ & $\begin{array}{r}\mathrm{NO}_{3}-\mathrm{N} \\
\text { load } \\
(\mathrm{kg})\end{array}$ & $\begin{array}{r}\mathrm{NO}_{3}-\mathrm{N} \text { load/ } \\
\text { Precipitation } \\
\left(\mathrm{kg} \mathrm{mm}^{-1}\right)\end{array}$ & $\begin{array}{r}\mathrm{P} \text { load } \\
(\mathrm{g})\end{array}$ & $\begin{array}{r}\mathrm{P} \text { load/ } \\
\text { Precipitation } \\
\left(\mathrm{g} \mathrm{mm}^{-1}\right)\end{array}$ \\
\hline 1 & Reference & 2 Nov 2007 & 2 Nov 2008 & 812 & 17.6 & 0.022 & 284 & 0.35 \\
2 & Controlled $(+0-50 \mathrm{~cm})$ & 2 Nov 2009 & 2 Nov 2010 & 896 & 24.3 & 0.027 & 134 & 0.15 \\
\hline 3 & Controlled $(+0-50 \mathrm{~cm})$ & 21 Apr 2010 & 21 Apr 2011 & 861 & 18.2 & 0.021 & 127 & 0.15 \\
\hline 4 & Reference & 3 Dec 2007 & 12 Feb 2008 & 175 & 15.1 & 0.086 & 240 & 1.37 \\
5 & Controlled $(+0-50 \mathrm{~cm})$ & 2 Dec 2009 & 12 Feb 2010 & 161 & 26.7 & 0.166 & 147 & 0.91 \\
\hline 6 & Reference & 3 Sep 2008 & 19 Nov 2008 & 122 & 1.2 & 0.010 & 19 & 0.16 \\
7 & Controlled $(+0 \mathrm{~cm})$ & 3 Sep 2010 & 17 Nov 2010 & 228 & 11.3 & 0.050 & 88 & 0.39 \\
\hline 8 & Reference & 19 Nov 2007 & 1 Feb 2008 & 191 & 8.9 & 0.047 & 129 & 0.68 \\
9 & Controlled $(+50 \mathrm{~cm})$ & 19 Nov 2010 & 2 Feb 2011 & 131 & 3.0 & 0.023 & 13 & 0.10 \\
\hline
\end{tabular}



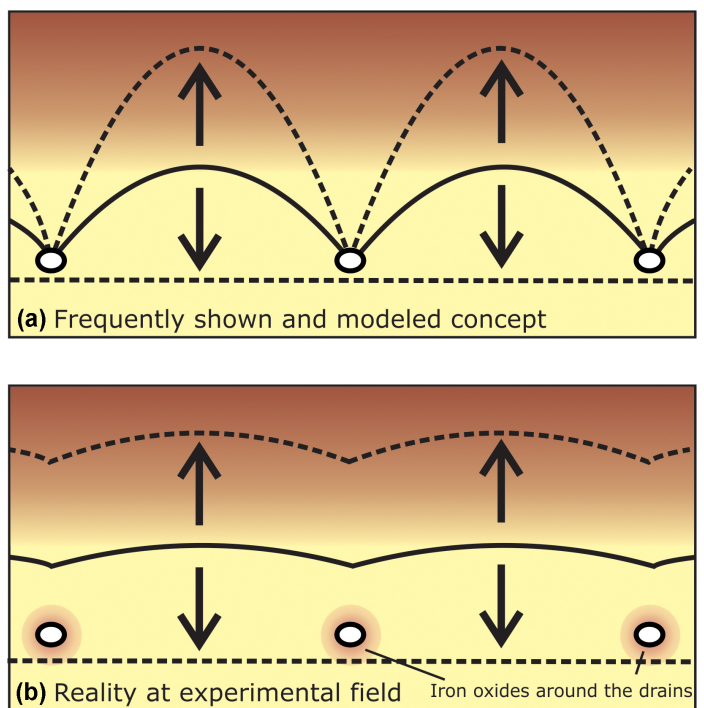

Figure 9. Comparison of (a) the common drainage concept with groundwater tables at the drain elevations and a large groundwater curvature between individual drains and (b) the situation at the experimental field with groundwater tables above the drains and a small groundwater curvature between the drains.

period 9 in Table 2. Lowering the overflow levels, however, induced higher drainage flow and higher loads. For example, the nutrient loads were relatively high during a controlled drainage period with lowered overflow levels (period 7). In Fig. 8, the cumulative discharge and load rates of change become steeper after lowering the overflow levels.

\section{Discussion}

The monitoring results produced valuable insights in the hydrological and hydrochemical effects of controlled drainage and in some practical issues for implementing controlled drainage and optimizing its effects in agricultural practice. First, the groundwater level monitoring revealed that on the pilot field (1) the groundwater levels were well above the drain levels during the winter drainage periods and (2) the groundwater curvature between the individual drains was limited $(2-3 \mathrm{~cm})$. In Fig. 9, the common drainage concept (e.g., De Vos et al., 2000) is compared with the situation at the experimental field. It is suggested that the groundwater discharge through the drains is limited due to an increased entrance resistance caused by the clogging of iron oxide around the drains. The formation of iron oxides around the water table and in tube drains is a known problem among farmers in the area and is related to reduced, ironrich groundwater that is mixed with nitrate- and oxygencontaining infiltrating water. The kinetics of this iron oxidation process and its effect on $\mathrm{P}$ immobilization were studied for the same pilot site by Van der Grift et al. (2014).

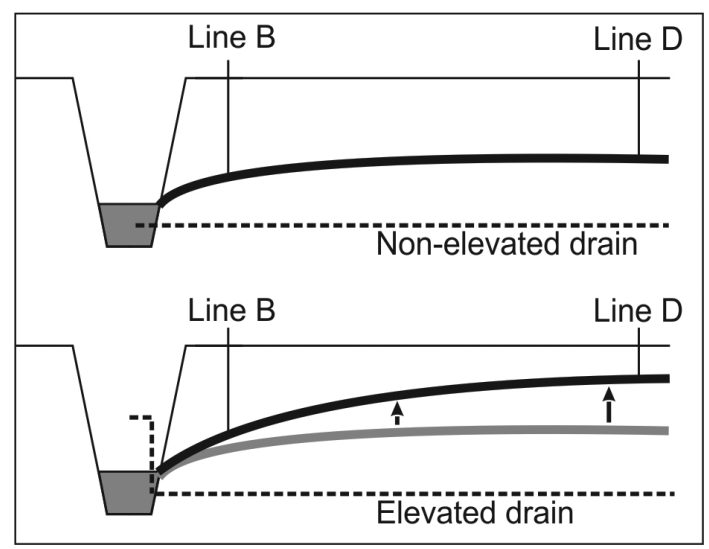

Figure 10. Transect-sketch of the effects of controlled drainage on groundwater levels in the experimental field.

From the groundwater level monitoring, a large difference was observed in the effect of controlled drainage between the piezometer transect at $5 \mathrm{~m}$ and at $80 \mathrm{~m}$ from the ditch. The less significant response of transect B is related to the dominant effect of direct drainage towards the ditch at $5 \mathrm{~m}$ distance. For the area further away from the ditch, drainage via tube drains is dominant and the effects of elevating the overflow levels are more significant. This concept, where most extra groundwater storage is realized further away from the ditch, is sketched in Fig. 10. Controlling the discharge and water levels in the ditch using a flexible weir would enhance the utilization of the groundwater storage capacity close to the ditch. Especially in areas with a dense network of open ditches, a combination of controlling both tube drain and open ditch discharges and water levels should be considered to increase the effectiveness of controlled drainage systems.

For the reduction of drought damage in summer, the groundwater storage during the spring period is crucial. To conserve water for the growing season, the overflow levels should be elevated as early as possible after the first manure application in February. After the first controlled drainage season, the overflow levels were not elevated until 15 April 2010. After this, a dry period started and increasing temperatures and grass growth enhanced evapotranspiration. No extra water was conserved for the summer period. At the end of the second drainage season, the overflow levels were elevated on 15 March 2011. This prevented the discharge of circa $160 \mathrm{~m}^{3}$ (ca. $18 \mathrm{~mm}$ ) of groundwater. The two scenarios are visualized in Fig. 11. The green line represents the groundwater levels when drain discharge was prevented and water was conserved by elevating the drain outlets on time. The purple line represents the groundwater levels when the overflow levels were not elevated before the drains became inactive and no discharge was prevented. Although elevating the overflow levels of the drains in early spring reduces drought in summer, the reduced discharge may hinder farm practices in early spring. At the end of the winter ban on ma- 


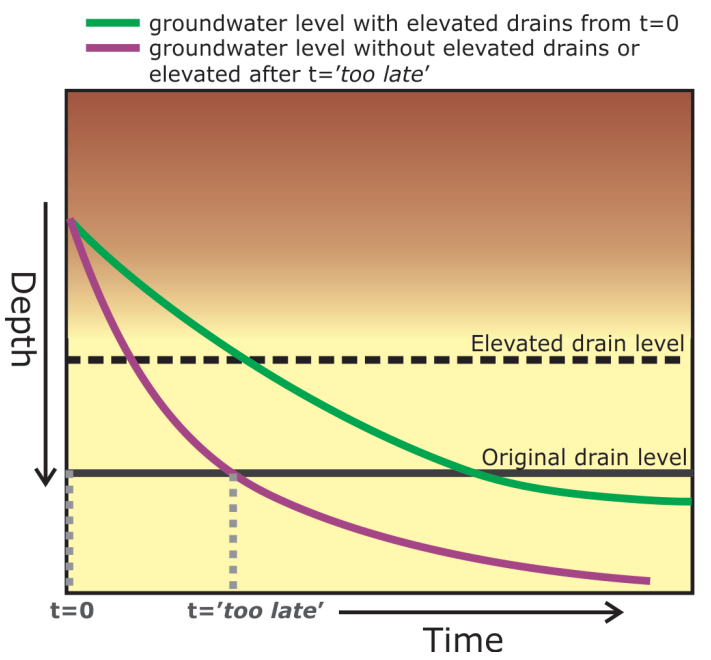

Figure 11. The crucial timing of elevating the overflow levels of controlled drainage at the end of the drainage season. Water can be conserved when the drain outlets are elevated before the groundwater levels are below the drains and the discharge has stopped.

nure spreading on 15 February, many livestock farmers are at or close to the maximum of their manure storage capacity. This forces them to apply manure in February and March, which may still be hampered by wet conditions, especially when the drainage is reduced by elevated overflow levels. A larger manure storage capacity could reduce the pressure for early manure applications and improve the effective use of controlled drainage systems to conserve water.

The introduction of controlled drainage did not reduce the $\mathrm{NO}_{3}-\mathrm{N}$ and $\mathrm{P}$ concentrations in the drain effluent. The $\mathrm{NO}_{3}-$ $\mathrm{N}$ concentrations even increased, although this was largely caused by elevated concentrations in one of the drains, which may or may not be related to controlled drainage. Due to the increased concentrations, the $\mathrm{NO}_{3}-\mathrm{N}$ loads increased after introducing controlled drainage. The $\mathrm{P}$ loads reduced, which is related to the reduced drain discharge. However, the comparison of water balances indicated that the reduced drain discharge is compensated by more overland flow and shallow groundwater flow, both to the surrounding fields and directly to the ditch. The increased contribution of these flow routes may increase the $\mathrm{NO}_{3}-\mathrm{N}$ and $\mathrm{P}$ loads to surface water. For $\mathrm{P}$, an average concentration of $0.65 \mathrm{mg} \mathrm{L}^{-1}$ was observed in overland flow in the Hupsel catchment (Rozemeijer and Van der Velde, 2014).

At the experimental field, the tube drains contributed $80 \%$ of the total yearly water discharge to the surface water and $90 \%$ of the total yearly $\mathrm{NO}_{3}-\mathrm{N}$ and $\mathrm{P}$ export (Rozemeijer et al., 2010a). This relatively large contribution is related to poor natural drainage through the comparatively thin unconfined aquifer. The relative importance of the tube drain discharge for water and nutrient transport also results in a relatively large impact of the introduction of controlled drainage. In areas with lower contributions of tube drain discharge, the effects of controlled drainage on water and nutrient transport may be less.

In the monitoring setup, continuous nutrient monitoring was successfully combined with passive samplers for average nutrient concentration monitoring. The equipment for continuous monitoring was applied for the registration of concentrations in the combined effluent of the three studied tube drains. Together with the continuous registration of discharge, the high-resolution nutrient concentration measurements enabled us to report detailed tube drain load patterns that could not have been measured by low-frequency grab sampling (see also Rozemeijer et al., 2010d). In addition, the direct responses of discharge and nutrient concentrations to the changes in overflow levels of the drains were measured. These responses would not have been captured by conventional grab sampling. The SorbiCell samplers were applied to measure average $\mathrm{NO}_{3}-\mathrm{N}$ concentrations for individual drains. This information became important to understand the increase of the combined effluent $\mathrm{NO}_{3}-\mathrm{N}$ concentrations after introducing controlled drainage. This increase could largely be explained by the increased concentrations of effluent from one of the three drains and is not necessarily related to the introduction of controlled drainage. The strategy of combining continuous water quality monitoring and passive samplers for individual sources is applicable for other monitoring studies as well.

\section{Conclusions}

The experimental setup produced valuable insights in the hydrological and hydrochemical effects of controlled drainage and in options to optimize the effects in agricultural practice. The introduction of controlled drainage effectively reduced the drain discharge and increased the groundwater storage in the studied field site. To achieve this, the overflow levels have to be elevated in early spring, before the drain discharge stops due to dryer conditions. The groundwater storage in the field would have been larger when the water levels in the adjacent ditch would have been controlled as well. The comparison of water balances before and after the introduction showed that the reduced drain discharge was partly compensated by more overland flow and shallow groundwater flow, both to the surrounding fields and directly to the ditch. Controlled drainage did not have clear positive effects for nutrient losses to surface water. The tube drains $\mathrm{NO}_{3}-\mathrm{N}$ concentrations and loads increased after introducing controlled drainage, which was largely related to elevated concentrations in one of the three monitored tube drains. The P loads via tube drainage decreased due to the lower drain discharge. However, this may be compensated by more P-rich overland flow and shallow groundwater flow. In areas with dense networks of open ditches, the effectiveness of controlled drainage for water conservation may be increased by also controlling the ditch water levels and discharges using flexible weirs. The pres- 
sure on manure application on dry fields directly after the end of the winter ban on manure spreading limits the optimal use of controlled drainage systems to conserve water in early spring.

Acknowledgements. The authors would like to thank Water Authority Rijn en IJssel for partially funding this study and especially Laurens Gerner, Annemarie Kramer and Bob van IJzendoorn are acknowledged for their cooperation. We also thank land owner Wim Kimmels for allowing our experiments on his farmland.

Edited by: B. Kronvang

\section{References}

De Jonge, H. and Rothenberg, G.: New device and method for fluxproportional sampling of mobile solutes in soil and groundwater, Environ. Sci. Technol., 39, 274-282, 2005.

De Vos, J. A., Hesterberg, D., and Raats, P. A. C.: Nitrate leaching in a tile-drained silt loam soil, Am. J. Soil Sci. Soc., 64, 517-527, 2000.

Díaz, R. J. and Rosenberg, R.: Introduction to environmental and economic consequences of hypoxia, Int. J. Water Resour. D., 27, 71-82, 2011.

Evans, R. O., Skaggs, R. W., and Gilliam, J. W.: Controlled versus conventional drainage effects on water quality, J. Irrig. Drain. E.ASCE, 121, 271-276, 1995.

Foley, J. A., DeFries, R., Asner, G. P., Barford, C., Bonan, G., Carpenter, S. R., Chapin, F. S., Coe, M. T., Daily, G. C., Gibbs, H. K., Helkowski, J. H., Holloway, T., Howard, E. A., Kucharik, C. J., Monfreda, C., Patz, J. A., Prentice, I. C., Ramankutty, N., and Snyder, P. K.: Global consequences of land use, Science, 309, 570-574, 2005

Ghane, E., Fausey, N. R., Shedekar, V. S., Piepho, H. P., Shang, Y., and Brown, L. C.: Crop yield evaluation under controlled drainage in Ohio, United States, J. Soil Water Conserv., 67, 465473, 2012.

Heinen, M., Noij, I. G. A. M., Heesmans, H. I. M., Van Groenigen, J. W., Groenendijk, P., and Thissen J. T. N. M.: A Novel Method to Determine Buffer Strip Effectiveness on Deep Soils, J. Environ. Qual., 41, 334-347, 2012.

Helmers, M., Christianson, R., Brenneman, G., Lockett, D., and Pederson, C.: Water table, drainage, and yield response to drainage water management in southeast Iowa, J. Soil Water Conserv., 67, 495-501, 2012.

Howarth, R. W.: Coastal nitrogen pollution: A review of sources and trends globally and regionally, Harmful Algae 8, 14-20, 2008.

Jaynes, D. B.: Changes in yield and nitrate losses from using drainage water management in central Iowa, United States, J. Soil Water Conserv., 67, 485-494, 2012.

Makarewicz, J. C., D’Aiuto, P. E., and Bosch, I.: Elevated nutrient levels from agriculturally dominated watersheds stimulate metaphyton growth, J. Great Lakes Res., 33, 437-448, 2007.

Rozemeijer, J. C. and Van der Velde, Y.: Temporal variability in groundwater and surface water quality in humid agricultural catchments; driving processes and consequences for regional water quality monitoring, Fund. Appl. Limnol., 184, 195-209, 2014.

Rozemeijer, J. C., Van der Velde, Y., Van Geer, F. C., Bierkens, M. F. P., and Broers, H. P.: Direct measurements of the tile drain and groundwater flow route contributions to surface water contamination: From field-scale concentration patterns in groundwater to catchment-scale surface water quality, Environ. Pollut., 158, 3571-3579, 2010a.

Rozemeijer, J. C., Van Der Velde, Y., McLaren, R. G., Van Geer, F. C., Broers, H. P., and Bierkens, M. F. P.: Integrated modeling of groundwater-surface water interactions in a tile-drained agricultural field: the importance of directly measured flow route contributions directly measured flow route contributions, Water Resour. Res., 46, W11537, doi:10.1029/2010WR009155, $2010 \mathrm{~b}$.

Rozemeijer, J. C., Van der Velde, Y., De Jonge, H., Van Geer, F. C., Broers, H. P., and Bierkens, M. F. P.: Application and evaluation of a new passive sampler for measuring average solute concentrations in a catchment-scale water quality monitoring study, Environ. Sci. Technol., 44, 1353-1359, 2010c.

Rozemeijer, J. C., Van der Velde, Y., Van Geer, F. C., De Rooij, G. H., Torfs, P., and Broers, H. P.: Improving load estimates for $\mathrm{NO}_{3}$ and $\mathrm{P}$ in surface waters by characterizing the concentration response to rainfall events, Env. Sci. Technol., 44, 6305-6312, 2010d.

Rozemeijer, J. C., Broers, H. P., Visser, A., Winegram, M., Borren, W., Gerner, L., Van IJzendoorn, B., and Kramer, A.,: Veldonderzoek naar de effecten van peilgestuurde drainage op grondwaterstanden, drainafvoeren en waterkwaliteit op het OostNederlands Plateau, Deltares-report 1201979-000-BGS-0001, Utrecht, the Netherlands, Deltares, Utrecht, the Netherlands, 2012 (in Dutch).

Statham, P. J.: Nutrients in estuaries - an overview and the potential impacts of climate change, Sci. Total Environ., 434, 213-227, 2012.

Seitzinger, S. P., Mayorga, E., Bouwman, A. F., Kroeze, C., Beusen, A. H. W., Billen, G., Van Drecht, G., Dumont, E., Fekete, B. M., Garnier, J., and Harrison, J. A.: Global river nutrient export: a scenario analysis of past and future trends, Global Biogeochem. Cy., 24, GB0A08, doi:10.1029/2009GB003587, 2010.

Van der Grift, B., Rozemeijer, J. C., Griffioen, J., and van der Velde, Y.: Iron oxidation kinetics and phosphate immobilization along the flow-path from groundwater into surface water, Hydrol. Earth Syst. Sci., 18, 4687-4702, doi:10.5194/hess-184687-2014, 2014.

Van der Grift, B., Broers, H. P., Berendrecht, W. L., Rozemeijer, J. C., Osté, L. A., and Griffioen, J.: High-frequency monitoring reveals nutrient sources and transport processes in an agriculturedominated lowland water system, Hydrol. Earth Syst. Sci. Discuss., 12, 8337-8380, doi:10.5194/hessd-12-8337-2015, 2015.

Van der Molen, D. T., Pot, R., Evers, C. H. M., and Van Nieuwerburgh, L. L. J.: Referenties en maatlatten voor natuurlijke watertypen voor de Kaderrichtlijn Water 2015-2021, STOWA rapportnummer 2012-31, STOWA, Amersfoort, the Netherlands, 2012 (in Dutch).

Van der Velde, Y., Rozemeijer, J. C., De Rooij, G. H., Van Geer, F. C., and Broers, H. P.: Field scale measurements for separation of catchment discharge into flow route contributions, Vadose Zone J., 9, 25-35, 2010a. 
Van der Velde, Y., Rozemeijer, J. C., de Rooij, G. H., van Geer, F. C., Torfs, P. J. J. F., and de Louw, P. G. B.: Improving catchment discharge predictions by inferring flow route contributions from a nested-scale monitoring and model setup, Hydrol. Earth Syst. Sci., 15, 913-930, doi:10.5194/hess-15-913-2011, 2011.

Van Ommen, H. C., Dijksma, R., Hendrickx, J. M. H., Dekker, L. W., Hulshof, J., and Van Den Heuvel, M.: Experimental assessment of preferential flow paths in a field soil, J. Hydrol., 105, 253-262, 1989.

Weijters, M. J., Janse, J. H., Alkemade, R., and Verhoeven, J. T. A.: Quantifying the effect of catchment land use and water nutrient concentrations on freshwater river and stream biodiversity, Aquat. Conserv., 19, 104-112, 2009.

Wesström, I, and Messing, I.: Effects of controlled drainage on $\mathrm{N}$ and $\mathrm{P}$ losses and $\mathrm{N}$ dynamics in a loamy sand with spring crops, Agr. Water Manage., 87, 229-240, 2007.

Winegram, M.: Effects of controlled drainage in an agricultural watershed on water storage andnutrient transport by using time series analysis, MSc Thesis, VU Amsterdam, the Netherlands, 2012.

Woli, K. P., David, M. B., Cooke, R. A., McIsaac, G. F., and Mitchell, C. A.: Nitrogen balance in and export from agricultural fields associated with controlled drainage systems and denitrifying bioreactors, Ecol. Eng., 36, 1558-1566, 2010.

Wösten, J. H. M., Bouma, J., and Stoffelsen, G. H.: Use of soil survey data for regional soil water simulation models, Soil Sci. Soc. Am. J., 49, 1238-1244, 1985. 